\title{
Corporate Citizenship, Social Responsibility, and Sustainability Reports as "Would-be" Narratives
}

\author{
Michel Dion ${ }^{1}$
}

Received: 8 June 2016 / Accepted: 18 April 2017 / Published online: 5 May 2017

(C) Springer International Publishing 2017

\begin{abstract}
Corporate citizenship, social responsibility and sustainability reports could be analyzed from a philosophical viewpoint. In this article, we will use Paul Ricoeur's hermeneutic philosophy to assess the narrativity of such reports. Out of a philosophical viewpoint, our exploratory study analyzes the contents of ten reports: two corporate citizenship reports (Disney; Abbott), three corporate social responsibility reports (WhiteWave; Comcast NBCUniversal; MGM Resorts International), and five sustainability reports (Whole Foods Market; Marriott; Johnson \& Johnson; Toyota; Honda). Those reports are arising in-time and are thus referring to past corporate events and phenomena (past-focused perspective). Sometimes such reports introduce a corporate world-dream that could emphasize various issues such as human dignity and inclusiveness/diversity, global health, and planetary stewardship (future-focused perspective). They could even convey a subversive ideal that could strongly shake the foundations of business. The way business corporations are understanding corporate citizenship and sustainability could, more or less radically, change the way we are doing business. However, those corporate citizenship, social responsibility and sustainability reports do not have any emplotment. They are thus stories that cannot be considered as narratives. We could call them "would-be" narratives.
\end{abstract}

Keywords Corporate citizenship, social responsibility and sustainability reports $\cdot$ Narratives · Paul Ricoeur

\section{Introduction}

As moral discourse, any narrative about organizational ethics refers to two different sets of messages: either implicit (unwritten/oral) messages as quasi-texts, or explicit/written messages as texts. In both cases, what is at stake is the basic system of organizational values, virtues,

Michel Dion

Michel.Dion@USherbrooke.ca

1 CIBC Research Chair on Financial Integrity, École de gestion, Université de Sherbrooke, 2500, boulevard Université, Sherbrooke, Québec J1K 2R1, Canada 
beliefs, and principles and the way they are applied through specific norms of organizational behaviour. The ethically-focused corporate documents include corporate mission/vision, values statement, codes of ethics and organizational policies, and corporate citizenship/social responsibility/sustainability reports. Corporate citizenship/social responsibility/sustainability reports are intrinsically linked to corporate history. Everything that is said, done, or told about good and evil makes integral part of corporate history. Corporate citizenship/social responsibility/sustainability reports refer to given actions and texts. Anyone could read action as if it would be text. Action as quasi-text means that how actions are externalized looks like how writing is fixing prior discourses (Ricoeur 1998).

Business corporations carry out sustainability/social responsibility/citizenship practices for various motives: value-driven motives (connected to corporate culture), stakeholder-driven motives (responsiveness to stakeholders' claims and expectations) and performance-driven motives (increasing financial performance) (Kilian and Hennigs 2014). However, safeguarding corporate image/reputation and avoiding environmental disasters are certainly very important motives (Özçelik et al. 2015). Corporate citizenship/social responsibility/sustainability reports are rarely addressing the ethical discourse, although they could use moral terms such as good/evil, just/unjust, true/untrue, ethical/unethical. Most of the time, moral aspects of business are not addressed. If sustainability implies an holistic perspective, then morality has to be part of the picture (Beckmann and Pies 2008). Various philosophical theories could be used to move to the level of ethical discourse, when dealing with corporate citizenship, social responsibility, or sustainability. Habermas' theory of communicative action is one of them (Reynolds and Yuthas 2008). Social contracts theories (Hobbes, Locke, Rousseau) and virtue ethics (Aristotle) constitute other paths to ethical discourse (Aßländer and Curbach 2014). Kantianism and Rawlsian theory of justice could also be used to give depth and meaning to corporate moral discourse (Hahn 2009). In this article, we will see to what extent Ricoeur's hermeneutics could help to us to better understand the import of corporate citizenship/social responsibility/sustainability reports. In our exploratory study, we will analyze ten reports: two corporate citizenship reports (Disney 2014; Abbott 2014); three corporate social responsibility reports (WhiteWave 2014-2015; Comcast NBCUniversal 2015; MGM Resorts International); five sustainability reports (World Foods Market 2012; Marriott 2014; Johnson and Johnson 2014; Toyota 2014; Honda Motor Co. 2015). Those reports should be considered as illustrative examples. Many textual analysis research methodologies could have been used: structuralist/semiological perspective, theory of basic human values, theory of cultural dimensions, or institutional isomorphism theory. However, the analysis of the ten reports is rather based on Ricoeur's philosophical approach of narratives. The contents of the ten reports will provide illustrative examples that make such corporate citizenship/social responsibility/sustainability reports more comprehensible from a philosophical viewpoint. Thus, our research question is the following one: insofar as we are using Ricoeur's philosophical approach, should such reports be considered as real narratives?

Firstly, literature review will help to understand to what extent corporate citizenship/ social responsibility/sustainability reports are responding to specific questioning, whether or not such organizational questioning is subject to various influences, including governments, industry, non-governmental organizations, consumers, and business partners. Secondly, we will observe the past-focused perspective which is endorsed through corporate citizenship/social responsibility/sustainability reports. We will explain how 
such reports are unveiling human suffering, corporate giving, and historical remnants as basic components of their past-focused perspective. Thirdly, we will see how corporate citizenship/social responsibility/sustainability reports could be future-focused, when describing corporate world-dreams as (more or less) concrete ways to imagine a better world for humankind. Finally, we will conceptualize corporate citizenship/social responsibility/sustainability reports as would-be narratives, while using Ricoeurian hermeneutics. The main contribution of this article is to assess to what extent corporate citizenship/ social responsibility/sustainability reports could be stories which are past-focused (and sometimes also future-focused), while having no emplotment at all. Having no emplotment implies that the story we are reading is nothing but a would-be narrative.

\section{Corporate Citizenship/Social Responsibility/Sustainability Reports: Literature Review}

Sustainability implies the belief that we cannot isolate social/environmental issues neither from economic benefits (Bowers 2010), nor from corporate culture (Adams and McNicholas 2007; Aras and Crowther 2009). The coherent alignment between social, economic and environmental issues could increase the reliability of corporate moral discourse, for internal and external stakeholders. The quality of annual reports (financial reporting) could even be correlated to corporate social responsibility (nonfinancial reporting) (Chiang et al. 2015). Moreoever, sustainability reporting is grounded on managers' concern for social and organizational change: multiple interrelated factors (coming from various sources, such as governments, industry, non-governmental organizations, and the social and cultural environment) send the message that there is a significant dissonance, so that real changes are needed (Adams and Whelan 2009). When managers are convinced that there is an urgent need for social and organizational change, they become more open to corporate citizenship/social responsibility/ sustainability reporting. Their conviction could be strengthened by industry influence, governmental regulations, and even by their local interests (Kunz 2016).

Nonfinancial disclosures are not strongly regulated. The Global Reporting Initiative remains the normative program of nonfinancial disclosure. However, entreprises could choose to disclose or not this or that information, to disclose it at a given time, or even to disclose only part of the information (Sisaye 2011; Cohen et al. 2012). The Global Reporting Initiative (GRI) is not necessarily attractive for shareholders. The intention behind nonfinancial reporting could be grounded not only on shareholders' expectations, but also on the industry influence as well as on institutional and cultural pressures (customers, distributors, and suppliers) (Tschopp and Nastanski 2014). Companies could be more encline to engage with GRI principles if their corporate social responsibility activities actually have great media exposure (Nikolaeva and Bicho 2011). In that case, corporate image/reputation seems to be the decisive factor for being engaged with the GRI principles. Sustainability reporting is often mirrored through corporate social responsibility initiatives, that is, a set of concrete measures expressing the corporate engagement towards socially sensitive issues (Schneider et al. 2010). It deals with issues that make social and nonsocial stakeholders, employees, customers and governements expecting corporate engagement towards a better collective wellbeing (Turker 2009). In the same way, corporate citizenship reports seem to be guided by stakeholders' pressures as well as the import of corporate culture (Lindgreen and Swaen 2005). Taking 
stakeholders' pressures into account means that corporate citizenship has been politicized. Corporate citizenship has become a power game in which the company and its stakeholders are searching for equilibrium. Focusing on corporate culture unveils the greatness of organizational values as they are implemented through managers' guidance. The notion of corporate citizenship is then referring to managers' personal ethics (Grit 2004), or at least, to the interconnectedness between core organizational values and managers' personal values.

Corporate citizenship, social responsibility, or sustainability reports are addressing similar topics, sometimes differently, sometimes quite similarly: business ethics and responsible business, health and safety in the workplace, environmental issues, respectful workplace, philanthropy, relationships with local communities, stakeholder engagement and corporate governance. According to Waddock (2016), the new narrative about the role of business in society refers to memes that put the emphasis on the wholeness of humankind (dignity, inclusiveness, diversity) as well as on planetary stewardship. Sustainability reports are mainly addressing the following topics: community involvement/philanthropy, health and safety, equal opportunity/workplace diversity, employee satisfaction, and human rights (Kolk 2003). Sustainability is a subversive concept that could radically question the way we are still doing business, in the Western as well as in the Eastern countries. Reconciling ecological and economic objectives implies to accept a trade-off thinking (Beckmann and Pies 2008). It is not crystal-clear that business corporations are taking such ideological challenge upon themselves. The path of corporate social responsibility seems to be easier, and less ideologically grounded. Corporate social responsibility (CSR) reports deal with similar issues: community development (including philanthropy), education and training, health and safety, health and disability, protection of the environment, employee welfare, relations with consumers (Fukukawa and Moon 2004; Thompson and Zakaria 2004; Chapple and Moon 2005). However, bribery, anticompetitive behavior, and even human rights are not really considered as the most important issues (Leszcynska 2012). Corporate social responsibility reports could endorse the triple bottom line concept, or focus on the strategic and processual dimensions (corporate social responsiveness), or even combines CSR principles with corporate social responsiveness and the real outcomes of corporate behavior (corporate social performance) (Sison 2009). In all cases, corporate social responsibility is never radically questioning the status quo. The notion of corporate citizenship could make business corporations more actively engaged with human rights issues. It could help managers considering their companies as providers of basic human rights. Any company whose actions and decisions are interpreted as providing human rights takes the challenge of corporate citizenship upon itself (Hahn 2012). Focusing on basic human rights could be interpreted as being concerned with interconnectedness and mutuality, and thus with love and others' wellbeing (Coombe 2011).

Sustainability seems to provide the (subversive) ideal as well as basic means to put it into practice. However, the notion of sustainability actively explores the macro level, while being absent in the micro level. The micro level is rather the calm land of corporate social responsibility. Corporate citizenship often tries to define the way the macro and the micro levels are interconnected and is thus conveying a subversive ideal, since any corporate citizen cannot consider business as pure business. Corporate citizenship makes the meso level connected to both the macro and the micro levels. It could provide a subversive ideal that strongly criticizes the bourgeois principle (the business of business is business). Corporate citizenship could even define a new role for companies: advocacy with respect to social issues, such as poverty (Boyle and Boguslaw 2007). 


\section{Past-Focused Perspective: Human Suffering, Corporate Giving, and Historical Remnants}

History implies three interconnected steps: the objectification of remnants (what?: events as historical remnants), the attempt to explain/understand past events (how?, why?: the whole process that makes events arising), and writing as the crucial component of historical narrative (writing the what, the how, and the why) (Dosse 2005). Historical narratives claim to represent past events (Ricoeur 2003). It is clearly the case with CEOs' autobiographies. However, past is both preserved and destroyed by historical re-presentations. Historical narratives are more fictive, and fictive narratives more mimetic than what positivistic perspectives about history generally acknowledge (Ricoeur 1979). Even the most objectivistic reading of past events could never get rid of the subjective thinker. CEOs' autobiographies which claim to be the most objective ones will remain subproducts of subjective thinkers. We could write the history of social representations about various objects (Ricoeur 2003). Ricoeur has identified the phenomenon of re-pre-senting-ness (représentance): historians consider historical knowledge of social representations as re-building the flow of past events (preservation), while recognizing that a given part of past events is lost and made unavailable (destruction). Re-pre-senting-ness involves three basic components. Firstly, "senting-ness" refers to the past's capacity to be actualized into the (existentially-rooted) present. Secondly, the "pre-" means that something has been priorly present and makes it possible for the existential root (ontic ground) to arise in the here and now. Thirdly, the "re-" implies that a new interpretation is drawn from the presence of past events into the agent's here-and-now. Re-pre-senting-ness makes narrative imagination its own servant. Re-pre-senting-ness is the basic function of history: it is the act of re-pre-senting past events. Past is both abolished and preserved in its historical remnants (Ricoeur 1997a; Amherdt 2004). Any corporate history implies that part of past corporate events and phenomena is safeguarded, while another part is irreparably lost. Corporate citizenship/social responsibility/sustainability reports have arisen in 1990s. It does not mean that nothing has been done until 1990. It only means that such reports were not usually published by business corporations before 1990s. Part of corporate citizenship/social responsibility/sustainability activities before 1990s could have been lost. Even good archivists in the organizational setting could hardly gather all corporate citizenship/social responsibility/ sustainability activities before 1990s, especially those connected to the founders' vision.

Corporate citizenship/sustainability/social responsibility reports often deal with suffering: for instance, corporate giving to local communities, health and safety in the workplace (work accident, burnout) as well as equal workplace opportunity (discrimination and harassment) are ethical issues which implicitly unveil possibilities of suffering. The individual who is using the other as a pure object (only as means to reach his/her own end) is dehumanizing himself/ herself (Ricoeur 1996). Ethical sight refers to justice and equality between all human beings. Ethical decision-making in the organizational setting enhances values of justice and fairness as well as basic human rights (Buchholz 1989). However, justice, fairness and basic human rights are existentially (and philosophically) ambiguous. Any organization could never be sure that its corporate citizenship/social responsibility/sustainability activities are just for its various stakeholders (including local communities in which they have operations) (Gates and Steane 2008). In its 2014 Citizenship Report, Disney seemed quite concerned with sick children in hospitals (p. 44). MGM Resorts International is particularly concerned with pediatric cancer treatment (p. 59), local hunger (p. 66-67), and with decent affordable housing (including for "homeless youth who identify as lesbian, gay, bisexual, or transgender", p. 61). Johnson \& 
Johnson is involved in "improving maternal and newborn survival and health, preventing the spread of infectious and neglected tropical diseases, and strengthening the healthcare system, including working to train healthcare workers" (p. 4, 10). Johnson \& Johnson is concerned with cancer treatment, orthopaedic needs, Alzheimer's disease, diabetes and cardiovascular disease (p. 21-22). However, it is quite amazing to find out, in the section dealing with intellectual property, the following sentence: "As part of our commitment to compassionate health care, Johnson \& Johnson believes in helping the world's poorest countries face local public health crises" (p. 57). If such issue would be really important, it should have been described in the section dealing with philantropy. As for health and safety in the workplace, Disney claimed "to significantly reduce employee exposure to conditions that may lead to work-related injury or illness" (p. 79). In its 2014 Sustainability Report, Marriott International explained that its occupational health services program has been set up in 1985. Occupational health services thus make an integral part of corporate culture. In its 2014 Citizenship \& Sustainability Report, Johnson \& Johnson admitted that the company has experienced several serious safety incidents in Johnson and Johnson 2014 (p. 4). The company acknowledged that it was a disappointing performance (p. 47).

Interpreting motives behind the action is reading action as "quasi-text". Actions are open works (Ricoeur 1977). Any action is breaking away from social agents (those who have undertaken such action). Action as quasi-text is developing its undesired consequences (Ricoeur 1998). Corporate citizenship/social responsibility/sustainability reports could be particularly concerned with motives behind attitudes, words, and behaviours. Interpretation is integral part of any explanation. It expresses subjective thought (Kierkegaard: truth as subjectivity). Explanation aims at objective analysis of past events (through causal relationships). Interpreting implies clarifying (Ricoeur 1998, 2003). When we are gathering information from various sources, we are interpreting the reliability and relevance of such sources. Trying to explain given phenomena is already interpreting what should be the most useful explanatory patterns. Writing discourses is interpreting what should be the best literary shaping of reality. Representation is the priviledged object of explanation and understanding, since it is an intentional act (Ricoeur 2003; Ricoeur 2013a, b). Corporate citizenship/social responsibility/sustainability reports try to gather information about corporate events and phenomena. Writing corporate citizenship/social responsibility/sustainability reports implies to gather information about environmental issues, health and safety in the workplace, relations with employees, consumers, and local communities. Sometimes, employees and citizens could observe that given organizations have not used self-criticism as hypercritical lenses/prisms. Hypocritical reading of gathered information could make organizations quite vulnerable to social/activist critique.

As they are closely linked to corporate history, corporate citizenship/social responsibility/ sustainability reports could re-member (rebuild the interconnectedness of past corporate events), re-mind (enhance the collective memory within the organizational culture), re-order (provide a sense of priorities), and re-interpret (give a new interpretation of corporate raison d'être) "unique" corporate past events and phenomena. Such ethically-focused corporate documents are not considering historical knowledge (about corporate past events and phenomena) as absolute knowledge. Insofar as they could be future-oriented and bearers of worlddreams, corporate citizenship/social responsibility/sustainability reports are impregnated with remnants of past corporate events and phenomena. Corporate citizenship/social responsibility/ sustainability reports could raise historical consciousness in the organizational life. Ethicallyfocused corporate documents are usually unveiling past-focused and/or future-focused 
orientation. If they are intrinsically connected to corporate history, ethically-focused corporate documents could help organizational members deepening their own historical consciousness.

Historians cannot make any having-been suddenly re-appearing (Michel 2013). Historical remnants do not signify anything by themselves. Questioning and interpreting could have remnants as objects of reflection. But remnants are something present. They preserve the otherness (strangeness) of past events and phenomena (Michel 2013). Historical remnants are various ways in which time falls into space (Faes 1987). Historical remnants often mirror how corporate past events and founders' vision and actions still exert a major role on the way corporate values and principles are actualized in the daily organizational life. In its 2014 Sustainability Report, Toyota referred to its founder Kiichiro Toyoda, while explaining its philosophy of customer service: accuracy + caring = trust (p. 29), its social contributions activities (p. 113), its philosophy regarding cultural and exhibit facilities (p. 137), and the Toyota Foundations' priorities (p. 139). In its 2015 Sustainability Report, Honda Motor Co. put the emphasis on the company's roots. The fundamental beliefs (respect for the individual and the Three Joys) have been created by the founders, Soichiro Honda and Takeo Fujisawa (p. 17). The Honda philosophy is so influential that it determines the way Honda deals with environmental, safety, quality, and social issues (p. 17). The 2015 Sustainability Report made clear that Honda philanthropy is not new: it has begun in 1960s (p. 78). In its Corporate Social Responsibility Report (2015), Comcast NBCUniversal referred to Comcast's founder, Ralph Roberts (Letter from the Chairman and CEO, Brian L. Roberts).

Any historian who would like to write the history of given business corporations will inevitably face the impossibility to safeguard everything from corporate past events and phenomena. He/she must accept that the having-been of corporate past events and phenomena cannot be fully re-covered. The having-been character of corporate past events and phenomena makes consciousness of historical loss arising. What has-been is related to the historical loss. The no-longer-be character of corporate past events and phenomena makes organizational members more aware of what has been preserved from the past. What is no-longer is related to historical remnants. We cannot become aware of what we have lost (having-been) without being aware of what we have safeguarded from destruction (no-longer-be). We cannot be aware of what we have preserved without being aware of what we have lost. There is dialectics between past's having-been and past's no-longer-be. The absent object (past events) implies that its no-longer-be aims at having-been (having-been-present). The object is absent in comparison with our re-pre-sentation of the object as-it-was. Whether its object is an event or a testimony, having-been cannot be observed (Ricoeur 1997a). Past has no-longer-be and having-been characters (Ricoeur 2009a). Existing means to be under the influence of past: the past is both no-longer-be (preservation: historical remnants) and having-been (destruction: historical loss). The having-been character of past events is often used to justify historical discourse (Ricoeur 1997a, 2003). But historical re-pre-sentations could be wrong, and distort the real import of past events (Ricoeur 2003). Corporate citizenship/social responsibility/ sustainability reports could be the locus of historical corporate awareness. They could make organizational members and other stakeholders more aware of which corporate commitments have been preserved/lost. In its 2014 Sustainability Report, Marriott International strongly asserted its core values: "put people first, pursue excellence, embrace change, act with integrity, and serve our world" (p. 2-3). The quality service (or "Put People First") was at the real origin of the company (p. 3, 17). Corporate citizenship/social responsibility/sustainability reports usually deal with extra-organizational issues (external stakeholders). In many business corporations, corporate citizenship/social responsibility/sustainability reports are new 
chapters of corporate history. History is basically narrative. Understanding history requires narrative intelligence (Ricoeur 1999). Corporate citizenship/social responsibility /sustainability reports have a basic no-longer-be component (historical remnants). Reading such reports makes people aware that some aspects of past events and phenomena have been lost (an having-been that cannot be recovered).

\section{Future-Focused Perspective: Corporate World-Dreams and a Better Future for Humankind}

Only people who are building future (for themselves, for their family, their organization, their society, and even for humankind) could judge past events and phenomena (Ricoeur 2003). This is precisely what corporate citizenship/social responsibility/sustainability reports could accomplish. Such ethically-focused corporate documents are conveying world-texts as world-dreams and could thus judge past corporate events and phenomena. Our choices and decisions are expressing the world we are dreaming about. Such "world-dreams" constitute the seeds of future thoughts and actions. Our world-dreams provide conscious/unconscious guidance to our values, virtues, attitudes, and behaviours. Organizational culture and corporate history really convey given world-dreams. When designing the contents and scope of our world-dreams, we must be very cautious. World-dreams could be part of sustainability practices and reports (Flyvbjerg 1993). When sustainability reports convey world-dreams, they could be considered as world-dreaming stories. Any dream about a sustainable world is rooted (or should be rooted) in the corporate values statement, since world-dream cannot be effective without basic values/ virtues. We cannot build up a new world without enhancing values/virtues focusing on happy/ good life. Prudence is required for actualizing our world-dreams in the organizational setting. We should rationally and clearly define core organizational values (within corporate values statement) and connect them to corporate citizenship/social responsibility/sustainability reports.

As social agents, organizational members are contributing to given modes of togetherness, whether or not such modes of togetherness actually coincide with the corporate ideal of togetherness: working-together (cooperation, team work, and basic human rights and liberties), living-together (love, compassion, and caring for each other), and hoping-together (sharing our world-dreams). Working-together, living-together, and hoping-together are forms of togetherness that make us responsible-for-others. Hopefully, organizational members as well as the company itself should actively be engaged with the same ideal of togetherness. Participating in togetherness makes us deepening our self-understanding and explanation/interpretation of corporate world-dreams. Corporate citizenship/social responsibility/sustainability reports use signs to underline corporate events and phenomena which characterize either the corporate history, or the organizational situation (present as what-is), or even its pro-jected future (worlddream as bearing given worldview). World-understanding will make possible to develop given world-interpretations, and then to express one's world-dream. A world-dream is the world someone would like to live in. It is not explicitly unveiled through his/her desires and fantasies, but rather through his/her speeches and deeds. One's world-dream is what makes someone changing the world in which he/she is living here-and-now. Corporate citizenship/social responsibility/sustainability reports could develop world-dreams, while mirroring a given worldview. There cannot be any world-dream without prior worldview, since world-dreams are rooted in worldviews. Corporate citizenship/social responsibility/sustainability reports could unveil a given world through the text itself (world-text). The world-text is grounded on 
a prior worldview (often rooted in corporate mission/vision), and could then express itsself as a world-dream (within corporate values statements and corporate citizenship/social responsibility/sustainability reports). We cannot understand some corporate citizenship/social responsibility/sustainability reports without seizing the hermeneutic movement from the worldview to the world-text as well as from the world-text to the world-dream. Corporate world-dreams are projecting new possibilities-to-be in the organizational setting. When conveying world-dreams, corporate citizenship/social responsibility/sustainability reports are future-focused documents. Such world-dreams are unveiling modes of accountability/responsibility-for-others.

Having a world-dream implies to be focused on the future. What we are dreaming about is not here-and-now. It has to be actualized. In the Honda's Sustainability Report (2015), we could observe the crucial importance to safeguard the trust of shareholders, customers, and society (p. 3, 6, 18, 22, 66). Honda's corporate slogan expressed the way individual dreams are actually considered: "The Power of Dreams (...) we can steadily move forward toward realization of a sustainable society in which everyone can pursue their dreams", said the President and CEO (p. 4; report, p. 78). Honda's President and CEO referred to the fundamental beliefs of the company, including the respect for the individual (initiative, equality/ fairness, and mutual trust) and the "Three Joys" (the joy of buying, the joy of selling, and the joy of creating). The Power of Dreams is clearly explained through three kinds of corporate commitment:

"Creating the Joys refers to sketching our dreams, moving ahead of the times to create new value through unrestrained ideas, and enhancing the fundamental beliefs that we call The Three Joys. Expanding the Joys refers to achieving our dreams with ever more people, contributing to local communities, and spreading The Three Joys throughout the world. Ensuring the Joys for the next generation refers to achieving the highest levels of environmental and safety performance aimed at the sustainable development of society, and carrying forward The Three Joys to future generations" (Honda, 2015 Sustainability Report, p. 18).

We have identified five corporate world-dreams: building a better tomorrow (Disney); having a healthy planet (Whole Foods Market); enhancing individual dignity every time and everywhere (MGM Resorts International); fostering global health (Abbott; Johnson \& Johnson; WhiteWave); creating harmony with people, society, and the environment (Toyota). Of course, there could be other corporate world-dreams. However, those five world-dreams can mirror what kinds of world-dreaming stories actually exist.

Building a Better Tomorrow In its 2014 Citizenship Report, Walt Disney Company focused on "building a brighter tomorrow". In his message (p. 4-5), Jay Rasulo, Senior executive Vice-president and Chief financial officer, explained how such focus implies to be deeply concerned with future generations. Building a brighter tomorrow mirrors deep concern for the future of the world (p. 47). The corporate aim to build brighter tomorrow presupposes to inspire individuals, families and communities, and thus refers to creativity and imagination. A brighter tomorrow is perceived as better tomorrow, that is, better world situation than the present one (p. 53). It is a "better tomorrow where the greatest stories have yet to be told" (p. 99). What we are dreaming about can be actualized. Dreams are not useless. They could be put in practice (p. 6). In order to build a brighter tomorrow, three main guidelines are asserted: "to conduct our business and create products in an ethical manner"; "to promote the happiness and well-being of kids and families everywhere", while trying to have a "greater impact in the 
decades to come"; "caring for the world we share" (p. 6, 13, 25). This is how Disney's worlddream could come true. Firstly, conducting business and creating products in an ethical way: “(...) encourage employees to act with integrity and in a manner that is consistent with Disney's Standards of Business Conduct; integrate citizenship into the day-to-day decision making on leadership; integrate citizenship into the conduct of Disney employees" (p. 54). Business ethics also applies to purchasing, recruitment, and product safety practices (p. 86, 88). Secondly, promoting happiness and well-being implies four concrete engagements: "make healthier living fun and accessible; nuture creative thinking skills to inspire kids to create the future they imagine; connect kids with nature to build lifelong conservation values; bring hope, happiness, and comfort to kids and families" (p. 25, 31, 37, 39). Thirdly, caring for the world means caring for animals and their physical environment as well as for the planet (p. 25, 40, 43). However, Disney acknowledged that its own corporate engagement is subject to uncertainty: "The Targets are subject to uncertainty; their completion is not guaranteed" (p. 13).

Having a Healthy Planet In its 2012 Green Mission Report, Whole Foods Market is dedicated to "a thriving, healthy planet" and put the emphasis on compassion and empathy "for the land and the creatures upon it" (p. 2, 7). A humane treatment of animals should thus be guided by basic attitudes (caring) and values (responsibility and respect) (p. 17). Comcast NBCUniversal tries to be "a catalyst for greater social change" (p.20). However, such hope is not followed by guidelines and principles of action. The corporate world-dream deals with the various ways to build "a more energy-efficient future" (p. 38).

\section{Enhancing Individual Dignity every Time and Everywhere MGM Resorts} International had a world-dream focusing on the dignity of every human being. In its Corporate Social Responsibility Report (2015), MGM Resorts International explained the essence of its "people philosophy": "we must do our best to promote fundamental respect for the dignity of all humanity - the hallmark of diversity and inclusion, and people relationships as the foundation of our business" (p. 12). MGM Resorts International seemed to make its corporate culture impregnated with a humanistic ideal, that is, a culture of diversity and inclusion: "we'are committed to promoting a work environment where all employees feel respected as human beings, comfortable in expressing their authentic gender identity" (p. 14). Such humanistic ideal is based on values of dignity, respect, and care (p. 64). Although MGM Resorts International is engaged in building better communities (p. 48,60), the company is mainly concerned with individual dignity.

Fostering Global Health Abbott's corporate ideal is "to help people live the best and fullest lives they can", as said Miles D. White, Chairman and CEO (p. 3). More specifically, such ideal is focusing on an healthy society: "every day, people around the world depend on our products to live healthier lives" (p. 7). What does it mean? The notion of health is largely applied to individuals (physical health, p. 8, 17, 40), communities, and even to economies: "Healthy economies contribute to healthy communities" (p. 7). Such notion of health is not crystal-clear. Good health (individuals) could have positive impact on global economy (p. 14). However, how could we measure an healthy economy, or an healthy community? Abbott did not address this critical issue. Abbott's engagement with stakeholders is more comprehensible: "stakeholders insights help us to develop new products that address unmet health needs; educate patients, healthcare professionals and others about emerging diseases and treatment options" (p. 10). Johnson \& Johnson's mission is "to help people live longer, healthier and 
happier lives" (Letter of the Chairman and CEO, Alex Gorsky, p. 2; report, p. 9, 18, 25). Johnson \& Johnson perceived itself as having a "continued ability to care", said the Chairman and CEO (p. 3). Caring for the world implies to care for each person individually, "one person at a time" (p. 18). It also requires to educate patients, doctors, and communities, while preventing diseases and promoting individual wellness (p. 23). In its 2014-2015 Corporate Social Responsibility Report, WhiteWave asserted its six core values: "integrity to produce food responsibly; individuals matter; informality to enjoy our work together; passion to lead; share what we do well; courage to learn and grow" (p. 4-5). Such values are defined as means to become a better company, and not as contributing to create a better world. In his letter accompanying the CSR report, Gregg Engles could be convinced that the company focuses "on what creates the most value for our consumers, our company and our planet" (p. 9). But it is not exactly the message that is sent through WhiteWave's values. Moreover, WhiteWave seemed proud to embrace a holistic approach to sustainability (p. 10, 13). But how does the notion of sustainability really allow to take non-holistic perspective? Sustainability is a holistic concept, by nature. A non-holistic notion of sustainability has nothing to do with sustainability. Nonetheless, WhiteWave wants "to change the world eats for the better" (p. 12, 47, 101, 109). It looks like a world-dream. WhiteWave fosters employees'empowerment, while trying to provide a model example: "People want to work at WhiteWave because we are creating the kind of company we can all be proud of, a place where we work to be the kind of change we want to see in the world" (p. 38); "We cherish all the ways in which we are unique, and we collaborate to create a culture where differences are respected, valued, and celebrated. We want our workplace to be one in which everyone can be their most authentic selves, and to give their best toward our shared goals and values" (p. 40).

Creating Harmony with People, Society, and the Environment In its 2014 Sustainability Report, Toyota Motor Co. referred to its five main principles that have been created by Risaburo Toyoda and Kiichira Toyoda, during the founding period of the company:

"Always be faithful to your duties, thereby contributing to the company and to the overall good; always be studious and creative, striving to stay ahead of the times; always be practical and avoid frivolousness; always strive to build a homelike atmosphere at work that is warm and friendly; always have respect for spiritual matters, and remember to be grateful at all times" (Toyota 2014 Sustainability Report, p. 7).

Toyota believed that mutual growth and mutual benefit (following from long-term relationships) are based on mutual trust (p. 54, 58, 65, 130). But mutual respect has to be strengthened in the first place, since there cannot be any trust without mutual respect between individuals (p. 55). Mutual trust and respect ultimately gives birth to a sense of unity between people (p. 78). Toyota philosophy is focusing on global harmony, that is, harmony with people, society, and the environment (p. 8-9, 104). While Honda emphasizes The Three Joys, Toyota considered that the company will be rewarded with smiles:

"Through our commitment to quality, constant innovation and respect for the planet, we aim to exceed expectations and be rewarded with a smile (...) The visionary management that we have in mind is making better cars that exceed customer expectations, and enriching lives in communities based on the shared values that have steered Toyota from the beginning, including the Guiding Principles at Toyota and the Toyota Way. In doing 
so, we are rewarded with smiles from customers and the public, leading to a stable base of business. We aim to generate such virtuous cycles and achieve sustainable growth"

In using the image of a tree, Toyota explained the basic link between its main principles and the fruits of Toyota Global Vision:

"The roots of the tree are (...) values expressed in the Five Main Principles of Toyoda, in the Guiding Principles at Toyota, and in the Toyota Way, which are the basis of our business. The fruit is our contribution to communities through making better cars that are chosen by customers and the public. The trunk of the tree, the result of these efforts, strengthens and stabilizes our base of business when large numbers of customers choose our products" (p. 11).

Organizational members decide the world they are dreaming about (their own worlddream). In every choice, individuals are facing the decision to enhance the world they would like to build up (Agarwal and Malloy 2000; Ashman and Winstanley 2006). A corporate world-dream remains a metaphor, since only human beings could dream about a better world. However, the corporate world-dream that is conveyed in corporate citizenship/social responsibility/sustainability reports could help us to deepen our self-understanding, as an individual as well as an organizational member. Company's world-dream and employees' world-dream could eventually be compared. If they are compatible one with the other, then it will probably be easier to implement the corporate world-dream. But if both world-dreams are incompatible (inconsistent), then they could open the way to an ethical crisis within the organization. As long as the corporate world-dream is accepted by most of organizational members, it could remain a viable ideal. But when many employees are uncomfortable with the corporate worlddream, then they could create an abyss between both worldviews. The most powerful worlddream (as ideal) will be that one which makes organizational members happier and proud to work in this organization. What we are seeing in the organizational setting (viewing) is not still what we would like to see (what we are dreaming about). But if a corporate world-dream is conveying the notion of a better tomorrow, then it tries to improve collective well-being. In doing so, it mirrors a humanistic hope: helping humanity to transform itself, to overcome its limitations, to enhance mutual understanding and respect. Every corporate world-dream plays it own (even minor) role in the constitution of humanism. Humanism is not particular worldview but rather the ultimate outcome of given worldviews (Merleau-Ponty 1967). What is specifically human has to be safeguarded, since it expresses our transcendental dignity. Humanity is then a responsibility for everybody. Everybody is responsible both for oneself and for the future of humankind (Levinas 2012). Sartre (1970) was opposing an essentialist humanism to an existentialist humanism. An essentialist humanity considers human being as an end, and thus human nature (essence precedes existence). An existentialist humanism rather puts the emphasis on human becoming (existence precedes essence): there is no essence. Choosing humanistic behaviors does not have the same consequences for essentialist humanism and for existentialist humanism. Everybody should explain the (essentialist or existentialist) basis of his/her own humanistic behaviors. In existentialist humanism, human nature does not exist at all. Everybody is responsible for what the world is becoming, because one's choices and actions convey a given representation of universal future. When we are choosing this action rather than other alternatives of action, we are saying that the world would be better if the principle of our action could be universally applied. Our own becoming exerts a role on the becoming of humankind (Sartre 1981). Our world-dream makes quite clear the world in 
which we would like to live, and thus the world that our actions are indeed building up. Corporate citizenship/social responsibility/sustainability reports often convey world-dreams dealing with human dignity, protection of the environment, and various means to enhance togetherness and mutual respect as well as common good. If those objects of world-dreams contribute to define humanistic perspective (Melé 2016), then they are promoting more humanistic ways to manage business corporations, although they could not always fulfil their promises.

\section{Narrativity and Corporate Citizenship/Social Responsibility/Sustainability Reports as "Would-be" Narratives}

Human being is the being who is continuously interpreting his/her reality (self, others, social groups, society, Nature, God/Ultimate Reality). Life is not a story, except if we interpret it as story (Ricoeur 2003). Self-identity could be so impenetrable that there is an "unspeakable self" (Ricoeur 2009a). Action is grounded on our ability to tell something about our deeds (Ricoeur 1996). Telling is saying who are the actors, what are their actions and motives, and how such actions have been undertaken. Telling is an act of attributing, and a preliminary explanation (Ricoeur 1996, 1999). Telling implies to deepen our reflection about narrated events (Ricoeur 1997a, b). Narrated history reveals who was acting/suffering (Ricoeur 1997a). Through narratives, we find out frail and deep dimensions of human self (Worms 2013). However, any narrative can never be morally neutral. Narrative is a primary laboratory of moral judgment (Ricoeur 1996). As would-be narratives, corporate citizenship/social responsibility/ sustainability reports cannot get rid of human suffering, as it is actualized in the organizational setting. Suffering is always referring to given interpretations of good/evil. To safeguard their moral character, corporate citizenship/social responsibility/sustainability reports must deal with human suffering. Moreover, suffering is temporally-based. That's why we could interpret past, present, and even future pains. Suffering happens in-time. Any corporate citizenship/social responsibility/sustainability report deals with suffering, while being temporally-rooted. Telling happens in-time and needs time. What needs time eventually acquires meaning, since a meaning is coming (in-the-future). Meaning is arising in-time, since human being cannot define anything (and thus giving any meaning to any reality) without taking his/her temporality into account. Temporality is the unity between what-has-been, what-is-made-present, and what-is-coming (Ricoeur 1997a; Ricoeur 2009a, b). Ricoeur (1992) referred to MerleauPonty's notion of time. The past is an old future as well as a recent present. The present is a future past (something that will become past) and a recent future (something we recently perceived as future). Every dimension of time, said Merleau-Ponty (2013), cannot be defined without referring to the other dimensions. We could only tell what has happened, actually happens, or will happen (Ricoeur 1998). There cannot be any narrative without time. Any corporate citizenship/social responsibility/sustainability report is evolving throughout corporate history. It must deal with various modes of human suffering, as they are actualized in the organizational setting. Suffering follows from the way our abilities to tell are reduced, or annihilated (Ricoeur 2013a). Corporate citizenship/social responsibility/sustainability reports could radically change the way business corporations are evolving as well as the way organizational members have relationships with other stakeholders.

From a Ricoeurian perspective, narrativity follows from two basic characteristics: withintime-ness and emplotment. On one hand, every event/phenomenon happens in-time. Being-in- 
time requires within-time-ness. We are aware of the presence of present things/beings around us. In Being and Time (1962, Part II, chapter VI), Heidegger explained that within-time-ness is grounded on Dasein's temporality. In the daily life, our actions take place in-time (Ricoeur 1999). Within-time-ness as everydayness is the basic character of care (Ricoeur 1997a, 1999). Events happen in-time. The act of telling also occurs in-time. Telling given stories happens here-and-now, but refers to past events and phenomena (past-focused perspective). Telling a story could also express some desires and hopes about the future (future-focused perspective). On the other hand, a narrative requires an emplotment, that is, an interconnectedness between past events and phenomena that gives meaning to the story. Such interconnectedness is made possible through the existence of a plot. The plot is what makes the story meaningful. Narratives imply both within-time-ness and emplotment. Most of stories are indeed narratives since they actually satisfy both criteria. CEOs' autobiographies actually meet those criteria and constitute narratives. Some corporate documents are not satisfying the two basic characteristics, since they do not express any relationship to past and future and because they do not have any plot. This is the case for corporate mission and vision, values statement, code of ethics, and organizational policies. In annual financial reports, the management message to shareholders often deals with some past events and the strategic (future-focused) orientation of the entreprise, so that the first criterion (within-time-ness) is actually met. However, most of the time, such management messages do not have any emplotment. Corporate citizenship/social responsibility/sustainability reports actually meet the first criterion (within-time-ness), but not the second one (emplotment). They are stories without emplotment. That's why we could call them "would-be narratives".

Some corporate past events are more or less explicitly described. Sometimes, a would-be narrative identifies a desirable future. But there is no emplotment. If there would be a plot, then the interconnectedness between past events, and even between past events and a desirable future would be clearly unveiled. Such disclosure would given meaning and depth to the story. For instance, a corporate narrative would put the emphasis on past events such as environmental disasters, harassment and discrimination scandals, while explaining how and why such events have occurred. An explanation is an answer to a past-focused why: an explanation unveils the interconnectedness between past events in order to make them meaningful. Corporate stories could add a world-dream that is conveying desirable future for humankind, or at least for the organization and its stakeholders. In that case, justification will be focused on the future. A justification asks a future-focused why: why would it not be possible to create a better tomorrow, a better world to live in? A real corporate narrative would make past events interconnected (explanation). It would eventually say why a new future has to be built up (justification). A would-be narrative is unable to explain past events (past-focused why) and to justify any desirable future (future-focused why). Corporate citizenship/social responsibility/ sustainability reports are stories which are told within-time. Very often, such reports are published on a yearly basis. In that case, they are telling what happened in the past year (past-focused) and sometimes fostering a corporate world-dream (future-focused). The contents of the story could vary from year to year, although the same corporate world-dream is always repeated.

The narrative process is structured by an emplotment, that is, the attempt to imitate the world of action. A narrative implies logical structure and temporal framework (a beginning, a middle, and the end) (Preuss and Dawson 2009). A plot takes place into given narrative tradition (Ricoeur 1992). It must innovate, while taking into account the powers of social conformism (leading to the status quo). Any plot is always connected to a narrative tradition, 
and thus to the dialectics of conformism and innovation. Organizational emplotment is the ongoing architecture of meanings throughout corporate history. Events make the story going on. They contribute to the development of the emplotment, and are connected to unifying motives and themes (Ricoeur 1998, 1999). Ricoeur put the emphasis on chronological and logical totalizing realized through narratives (D'Almeida 2006). The event is an emplotment as either the mediatory synthesis of various intents (as claimed and explicitly unveiled intents), causes, and chance, or the mediatory synthesis of different events and characters. An emplotment is mediating permanency and change (Ricoeur 2013a, b). An emplotment puts different events within a given story. It takes into account heterogeneous factors, such as circumstances and chance, social agents and their projects, motives, and attitudes (such as cooperation vs hatred) (Ricoeur 1998). An organizational emplotment is the on-going architecture of multiple meanings throughout the interconnectedness of various corporate events and phenomena. Emplotment is imitating actions that readers have already fore-understood (Darwish 2011).

The way organizational members has fore-understood corporate past events and phenomena influence their reading of corporate would-be narratives, such as corporate citizenship/ social responsibility/sustainability reports. Any fore-understanding of actions (as quasi-texts) calls for a better understanding of the stories (texts) which are referring to those past actions. Narratives provide something to be aware of (present-focused) and something to understand (as pro-ject, and future-focused) (Ricoeur 2003). Narratives constitute the re-description of the action (whose referent is already-there-action) (Ricoeur 1996, 1998). Narratives determine who is acting and convey given representations of reality (Ricoeur 1996). Narratives imply representations of reality. Any understanding/interpretation process implies the power to do/ say something, the power to tell stories, and the power to take responsibility upon ourselves/to be accountable for our actions (Ricoeur 2003). Those capabilities define what Ricoeur called the "capable man". Ricoeur dealt with the anthropology of the "capable man", including those four basic capabilities (Ricoeur 2003; Ricoeur 2009a). Each of those capabilities has practical and theoretical impact on the way corporate citizenship/social responsibility/sustainability reports are developed in the organizational setting. The capability to be accountable for actions, words, and gestures implies people who are actually accountable for their decisions. Accountability implies the capability to take consequences of our actions upon ourselves, more particularly the capability to put our mistakes right and to accept reasonable punishment. Accountability is the imputation of specific actions to social agents whose attitudes and behaviours really meet the following conditions: being good, being just, being in accordance with rational duties, and being wise, in given circumstances (Ricoeur 1996). Accountability is focusing on others' wellbeing, since we are responsible-for-others (Ricoeur 2009a). Our accountability/responsibility is grounded on the belief that we could trust others and that others could trust us. Breaking our promises is betraying others' expectation towards our own reliability. Being reliable implies to rightly respond to others' expectations towards our speech, thought, and action (Ricoeur 1996). Responsibility-for-others is limited, since an unlimited (infinite) responsibility would make mineness of given actions disappearing (Ricoeur 2009a).

Corporate citizenship/social responsibility/sustainability reports deal with corporate accountability in various ways. Business corporations are responding to institutional expectations and complying with laws and regulations. Four basic topics are then addressed: corruption, human rights, lobbying, and corporate law.

Corruption In its 2014 Sustainability Report, Marriott International put the emphasis on its anti-corruption policy, while referring to the U.S. Foreign Corrupt Practices Act and to the UK 
Bribery Act (p. 12). Johnson \& Johnson is also engaged in complying with the Foreign Corrupt Practices Act (p. 28).

Human Rights In its 2014 Citizenship Report, Abbott asserted that the company complies with the Universal Declaration of Human Rights (p. 53). Johnson \& Johnson explained that critical employees have received human rights training (p. 34). "Critical employees" are employees whose positions are "most sensitive to human rights infringements" (p. 39). It is not self-evident to know the various positions which make someone a "critical employee". J \& $\mathrm{J}$ is proud to say that the company has signed the UN Global Compact in 2013 and claims that such fact contributes "to reflect the Company's commitment to fundamental rights at work" (p. 49).

Lobbying Johnson \& Johnson admitted that the company tries "to influence and shape external regulations that in turn help raise the standard of care and, thereby, help people live longer, healthier, happier lives" (p. 4, 25). J \& J seems to believe that its lobbying activities are always, without any doubt, focusing of community needs.

Corporate Law Honda made quite clear that the company complies with all laws and regulations, but particularly with some American regulations, including the Securities Exchange Act of 1934, the Exchange Act of 1933, the Dodd-Frank Wall Street Reform and Consumer Protection Act, the US Transportation Recall Enhancement, Accountability, and Documentation Act (TREAD Act) (p. 24, 26).

As would-be narratives, corporate citizenship/social responsibility/sustainability reports could be past-focused as well as future-focused documents. They are past-focused when they are mirroring some basic corporate realizations. But they could be future-focused when they are conveying corporate world-dreams, which are unveiling modes of accountability and responsibility-for-others. A corporate world-dream is neither a slogan, nor an utopia. It is rather an ideal that the company is pursuing, while defining concrete means to actualize it in the daily organizational life. Corporate citizenship/social responsibility/sustainability reports are addressing various expressions of human suffering (for instance, the poor and the needy vs the health care system; discrimination against Blacks/Natives in post-secondary schools). Such ethically-focused corporate documents are centered on corporate responsibility-for-others, and on various ways to release people from existentiell suffering.

\section{Conclusion}

Corporate citizenship/social responsibility/sustainability reports could convey world-dreams that should be translated into corporate commitments/actions. They are then future-focused corporate documents. They constitute would-be narratives which could more or less strongly support given world-dreams as innovative modes of responsibility-for-others and which could open the way to philosophical/existentiell questioning. It is particularly true for sustainability report when they are conveying world-texts (as world-dreams) that must be translated into corporate commitments. Such corporate documents are telling a story (focusing on past events, and sometimes looking at the future), without having any plot. A would-be narrative is thus paradoxical: it is not what it appears to be. There seems to be a narrative, but there is no emplotment. Corporate citizenship/social responsibility/ 
sustainability could convey given world-dreams that are unveiling new modes of togetherness that express our being-responsible-for-others. However, insofar as they do not have any plot, their corporate world-dreams about new forms of togetherness could be seen as a form of window-dressing.

Corporate citizenship/social responsibility/sustainability reports are would-be narratives that could be analyzed from a philosophical perspective. While being future-oriented and bearing world-dreams, such reports are impregnated with remnants of past corporate events and phenomena. They are thus influencing the way the organization has developed its historical consciousness. They could help organizational members to deepen their own historical consciousness. The philosophical challenge of such reports is to make possible organizational self-criticism (about any choice of values/ethical issues) as well as the capacity to express various meanings through given symbols. Those reports must become more connected to existentiell predicament, and to philosophical (intuitive) questioning about the meaning of organizational life. Seizing corporate citizenship/social responsibility/sustainability reports as would-be narratives is a way to take into account the interconnectedness between narrativity and time. Ultimately, would-be narratives are unveiling the absence of emplotment, and thus the absence of others' role in past events (and even for the desirable future). The way others become absent in would-be narratives could provoke the degeneration of being-withothers in the organizational setting. Being is being-with others (Heidegger 1962). The absence of any emplotment could make togetherness decreasing in the organization. When such reports are denying the interconnectedness of corporate past events, and even when they do not relate them to desirable future, they are reducing otherness and togetherness to pure means (utensils). Would-be narratives could have the power to dehumanize relationships in the organizational setting, when the story that is told has no plot at all.

This is an exploratory study. The ten reports that have been analyzed should be seen as illustrative examples. This is clearly a limitation of the study. A philosophical approach of corporate citizenship/social responsibility/sustainability reports could put light on its unveiled components. However, such reports could be more or less closely linked to other ethically-focused corporate documents, such as the corporate mission/vision, the values statement, or the corporate code of ethics. Future research could check to what extent their narrativity could be more or less different than that of corporate citizenship/social responsibility/sustainability reports. It could also be relevant to analyze the intertextuality between such corporate documents and see to what extent it has an impact on narrativity. This study was using Ricoeur's hermeneutics. A different view could follow from the use of other hermeneutic philosophies: Friedrich Schleiermacher, Wilhelm Dilthey, or Hans-Georg Gadamer. This is clearly a limitation of our study. Ricoeur's hermeneutics cannot give the final word about the philosophical import of corporate citizenship/social responsibility/ sustainability reports.

A philosophical approach of corporate citizenship/social responsibility/sustainability reports could help its writers to seize the real nature of the stories they are telling. Writers could better understand the philosophical (intuitive) questioning from the moment when organizational members are reading those reports. Writers could become more aware that such reports could be stories, but not narratives. Those who write such reports will better know that narrativity requires emplotment and that emplotment makes more meaningful the continuum between the past, the present, and the future. If those writers want to create meaningful stories for the organizational life and culture, they must introduce an emplotment within their storytelling. 


\section{References}

Abbott. 2014 Citizenship Report, 107 p. http://dam.abbott.com/global/documents/pdfs/abbott-citizenship/globalreports/2014_Global_Citizenship_Report_121515-Interactive-with\%20GRI-v13.pdf.

Adams, Carol A., and Patty McNicholas. 2007. Making a difference. Sustainability reporting, accountability and organisational change. Accounting, Auditing \& Accountability Journal 20 (3): 382-402.

Adams, Carol A., and Glen Whelan. 2009. Conceptualising future change in corporate sustainability reporting. Accounting, Auditing \& Accountability Journal 22 (1): 118-143.

Agarwal, James, and David Cruise Malloy. 2000. The role of existentialism in ethical business decision-making. Business Ethics: A European Review 9 (3): 143-154.

Amherdt, François-Xavier. 2004. L'herméneutique philosophique de Paul Ricoeur et son importance pour l'exégèse biblique. Paris: Éditions du Cerf.

Aras, Güler, and David Crowther. 2009. Corporate sustainability reporting: A study in Disingenuity? Journal of Business Ethics 87 (1, Suppl): 279-288.

Ashman, Ian, and Diana Winstanley. 2006. The ethics of organizational commitment. Business Ethics: A European Review 15 (2): 142-153.

Aßländer, Michael S., and Janina Curbach. 2014. The corporation as Citoyen? Towards a new understanding of corporate citizenship. Journal of Business Ethics 120 (4): 541-554.

Beckmann, Markus, and Ingo Pies. 2008. Sustainability by corporate citizenship. The moral dimensions of sustainability. The Journal of Corporate Citizenship 2008 (31): 45-57.

Bowers, Tom. 2010. From image to economic value: A genre analysis of sustainability reporting. Corporate Communications: An International Journal 15 (3): 249-262.

Boyle, Mary-Ellen, and Janet Boguslaw. 2007. Business, Poverty and Corporate Citizenship. Naming the Issues and Framing Solutions. The Journal of Corporate Citizenship 26: 101-120.

Buchholz, Rogene A. 1989. Business environment and public policy. Implications for Management and Strategy Formulation. Englewood Cliffs: Prentice Hall.

Chapple, Wendy, and Jeremy Moon. 2005. Corporate social responsibility (CSR) in Asia. A seven-country study of CSR web site reporting. Business and Society 44 (4): 415-441.

Chiang, Hsiangtsai, Li-Jen He, and Cang-Fu Shiao. 2015. Financial reports quality and corporate social responsibility. Asian Economic and Financial Review 5 (3): 453-467.

Cohen, Jeffrey R., Lori L. Holder-Webb, Leda Nath, and David Wood. 2012. Corporate reporting of nonfinancial leading indicators of economic performance and sustainability. Accounting Horizons 26 (1): 65-90.

Comcast NBCUniversal. 2015 Corporate Social Responsibility Report, 48 p. http://corporate.comcast. com/images/2015-Corporate-Social-Responsibility-Report.pdf.

Coombe, Duncan. 2011. Corporate citizenship. An Expression of Love. The Journal of Corporate Citizenship 42: 93-102.

D’Almeida, Nicole. 2006. La perspective narratologique en organisations. In Responsabilité sociale : vers une nouvelle communication des entreprises ? ed. P. de la Broise and T. Lamarche, 27-38. Paris: Presses universitaires du Septentrion.

Darwish, Housamedden. 2011. Paul Ricoeur et la problématique de la méthode dans l'herméneutique. Interpréter, comprendre et expliquer dans les théories du symbole, de la métaphore et du récit. Paris: L'Harmattan.

Dosse, François. 2005. Paul Ricoeur, Michel de Certeau et l'Histoire. Entre le dire et le faire. In L'histoire entre mémoire et épistémologie. Autour de Paul Ricoeur, ed. Bertrand Müller, 149-182. Lausanne: Payot.

Faes, Hubert. 1987. La Nature peut-elle être racontée? Revue de sciences philosophiques et théologiques 71 (3): $421-432$.

Flyvbjerg, Bent. 1993. Aristotle, Foucault, and progressive Phronesis: Outline of an applied ethics for sustainable development. In Applied ethics - a reader, ed. E.R. Winkler and J.R. Coombs, 11-27. Oxford/Cambridge: Blackwell.

Fukukawa, Kyoko, and Jeremy Moon. 2004. A Japanese model of corporate social responsibility? A study of website reporting. The Journal of Corporate Citizenship 16: 45-59.

Gates, Donald, and Peter Steane. 2008. Ambiguities of justice in a global marketplace. How are ethical and theological considerations relevant to policymakers? Management Decision 46 (8): 1146-1165.

Grit, Kor. 2004. Corporate citizenship: How to strengthen the social responsibility of managers? Journal of Business Ethics 53 (1-2): 97-106.

Hahn, Rüdiger. 2009. The ethical rational of business for the poor - Integrating the concepts bottom of the pyramid, sustainable development, and corporate citizenship. Journal of Business Ethics 84 (3, Suppl): 313-324.

Hahn, Rüdiger. 2012. Corporate citizenship in developing countries: Conceptualisations of human-rights-based evaluative benchmarks. African Journal of Business Ethics 6 (1): 30-38.

Heidegger, Martin. 1962. Being and Time. New York: Harper and Row Publishers. 
Honda Motor Co. 2015 Sustainability Report, 103 p. http://world.honda.com/sustainability/report/pdf/2015 /Honda-SR-2015-en-all.pdf.

Johnson \& Johnson. 2014 Citizenship \& Sustainability Report, 121 p. https://jnj.brightspotcdn.com/c3/ce/4cc39 cbe488c87719de41d1e9721/2014-jnj-citizenship-sustainability-report.pdf.

Kilian, Thomas, and Madine Hennigs. 2014. Corporate social responsibility and environmental reporting in controversial industries. European Business Review 26 (1): 79-101.

Kolk, Ans. 2003. Trends in sustainability reporting by the fortune global 500. Business Strategy and the Environment 12 (5): 279-291.

Kunz, Michelle B. 2016. A proposed investigation of corporate social responsibility reporting on fortune 500 corporate websites. Journal of Leadership, Accountability and Ethics 13 (2): 93-102.

Leszcynska, Agnieszka. 2012. Towards shareholders' value: An analysis of sustainability reports. Industrial Management \& Data Systems 112 (6): 911-928.

Levinas, Emmanuel. 2012. Humanisme de l'autre homme. Paris: Le livre de poche.

Lindgreen, Adam, and Valérie Swaen. 2005. Corporate citizenship: Let not relationship marketing escape the management toolbox. Corporate Reputation Review 7 (4): 346-363.

Marriott International. 2014 Sustainability Report, 46 p. http://www.marriott. com/Multimedia/PDF/CorporateResponsibility/2014SustainRpt_FNL_lr.pdf.

Melé, Domenec. 2016. Understanding humanistic management. Humanistic Management Journal 1 (1): 33-55.

Merleau-Ponty, Maurice. 1967. Éloge de la philosophie et autres essais. Paris: Gallimard.

Merleau-Ponty, Maurice. 2013. Phénoménologie de la perception. Paris: Gallimard.

MGM Resorts International. 2015 Corporate Social Responsibility Report, 118 p. https://www.mgmresorts. com/csr/pdf/2015-MGM-Resorts-CSR-Annual-Report.pdf.

Michel, Johann. 2013. L'énigme de la représentance, Paul Ricoeur: penser la mémoire, eds. F. Dosse and C. Goldenstein. 277-290. Paris: Seuil.

Nikolaeva, Ralitza, and Marta Bicho. 2011. The role of institutional and reputational factors in the voluntary adoption of corporate social responsibility reporting standards. Journal of the Academy of Marketing Science 39 (1): 136-157.

Özçelik, Funda, Burcu Avci Öztürk, and Sevda Gürsakal. 2015. Corporate Sustainability: A Research on Firms That Issue Sustainability Reports in Turkey. Business and Economic Research Journal 6 (3): 33-49.

Preuss, Lutz, and David Dawson. 2009. On the quality and legitimacy of Green narratives in business: A framework for evaluation. Journal of Business Ethics 84 (1, Suppl): 135-149.

Ricoeur, Paul. 1977. Expliquer et comprendre. Sur quelques connexions remarquables entre la théorie du texte, la théorie de l'action et la théorie de l'histoire. Revue philosophique de Louvain 75 (25): 126-147.

Ricoeur, Paul. 1979. La fonction narrative. Études théologiques et religieuses 54 (2): 209-230.

Ricoeur, Paul. 1992. Lectures 2- La contrée des philosophes. Paris: Éditions du Seuil.

Ricoeur, Paul. 1996. Soi-même comme un autre. Paris: Seuil.

Ricoeur, Paul. 1997a. Temps et récit. II- La configuration dans le récit de fiction. Paris: Seuil.

Ricoeur, Paul. 1997b. Temps et récit. III- Le temps raconté. Paris: Seuil.

Ricoeur, Paul. 1998. Du texte à l'action - Essais d'herméneutique II. Paris: Seuil.

Ricoeur, Paul. 1999. Temps et récit. I- L’intrigue et le récit historique. Paris: Seuil.

Ricoeur, Paul. 2003. La mémoire, l'histoire, l'oubli. Paris: Seuil.

Ricoeur, Paul. 2009a. Le conflit des interprétations. Essais d'herméneutique. Paris: Seuil.

Ricoeur, Paul. 2009b. Parcours de la reconnaissance. Paris: Gallimard.

Ricoeur, Paul. 2013a. Cinq études herméneutiques. Genève: Labor et Fides.

Ricoeur, Paul. 2013b. Histoire et herméneutique. In Paul Ricoeur : penser la mémoire, ed. F. Dosse and C. Goldenstein, 13-46. Paris: Seuil.

Sartre, Jean-Paul. 1970. L'existentialisme est un humanisme. Paris: Nagel.

Sartre, Jean-Paul. 1981. L'être et le néant. Essai d'ontologie phénoménologique. Paris: Gallimard.

Schneider, Jennifer L., Anna Wilson, and Joseph M. Rosenbeck. 2010. Pharmaceutical companies and sustainability: An analysis of corporate reporting. Benchmarking: An International Journal 17 (3): 421-434.

Sisaye, Seleshi. 2011. Ecological systems approaches to sustainability and organizational development. Emerging trends in environmental and social accounting reporting systems. Leadership and Organization Development Journal 32 (4): 379-398.

Sison, Alejo José G. 2009. From CSR to Corporate Citizenship: Anglo-American and Continental European Perspectives. Journal of Business Ethics 89 (3, Suppl): 235-246.

Thompson, Paul and Zaruna Zakaria. 2004. Corporate Social Responsibility Reporting in Malaysia. Progress and Prospects. Journal of Corporate Citizenship (13) 125-136.

Toyota Motor Co. 2014 Sustainability Report, 153 p. http://www.toyota-global. com/sustainability/report/sr/pdf/sustainability_report14_fe.pdf. 
Trevino, Linda K., Michael Brown, and Laura Pincus. 2003. A qualitative investigation of perceived executive ethical leadership: Perceptions from inside and outside the executive suite. Human Relations 56 (1): 5-37.

Tschopp, Daniel, and Michael Nastanski. 2014. The harmonization and convergence of corporate social responsibility reporting standards. Journal of Business Ethics 125 (1): 147-162.

Turker, Duygu. 2009. Measuring corporate social responsibility: A scale development study. Journal of Business Ethics 85 (4): 411-427.

Waddock, Sandra. 2016. Foundational memes for a new narrative about the role of business in society. Humanistic Management Journal 1 (1): 91-105.

Walt Disney Company. Disney Citizenship 2014. Performance Summary, 128 p. https://ditm-twdc-us.storage. googleapis.com/FY14-Performance-Summary.pdf.

WhiteWave. 2014-2015 Corporate Social Responsibility Report, 123 p. http:/www.whitewave.com/wpcontent/uploads/2016/07/WhiteWave-CSR-2014_2015-Full-Report.pdf.

World Foods Market. 2012 Green Mission Report, 58 p. https://www.wholefoodsmarket. com/sites/default/files/media/Global/PDFs/2012GreenMissionReport.pdf.

Worms, Frédéric. 2013. Souffrant, agissant et vivant. In Souffrance et douleur. Autour de Paul Ricoeur, ed. C. Martin and N. Zaccaï-Reyners, 37-45. Paris: Presses universitaires de France. 